\title{
住宅の小屋裏と床下空間の熱・湿気性状 EXPERIMENTAL STUDY ON TEMPERATURE AND HUMIDITY VARIATIONS IN ATTIC AND CRAWL SPACES OF HOUSE
}

\author{
宮田靖久*, 松本 衛** \\ Yasuhisa MIYATA and Mamoru MATSUMOTO
}

\begin{abstract}
In this study, detailed behaviors of temperature and humidity variations in attic and crawl space are measured continuously over years with related external conditions such as solar radiation, precipitation, air temperature, humidity and air velocity. Data obtained have sufficient accuracy to discuss system identification of those spaces and validation of the system models. Of two experimental houses having same configuration and different specification, behaviors above mentioned are measured continuously during one and half year. In this paper, results of measurements are shown and characteristic behaviors of temperature and humidity variations are discussed. In attic, humidity variations are affected explicitly moisture ab/desorption of roof board. Of moisture flow in crawl space, ground surface acted as moisture sink during summer.
\end{abstract}

Keywords : attic space, crawl space, temperature, humidity, moisture absorption, moisture desorption

小屋裹, 床下, 温度, 湿度, 吸湿, 放湿

\section{1.はじめに}

一般に住宅における小屋裏や床下は，建築の熱・湿 気的な緩衝空間として設置されてきたが, 外界からの気 温・日射・降雨・風などの気象変動と, 居室からの加熱 や水分供給とによって, 複雑な温湿度の変化性状を示 し，それ故に結露被害等の問題も少なからず発生して， 防湿的対応に苦虑する建築空間の一つであった。

これまで小屋裹や床下の熱・湿気に関する研究の中 で理論的な取組みを行なっているものは極めて少なく,

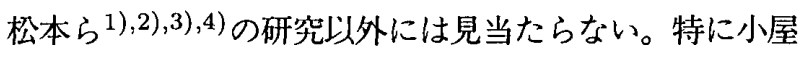
裹の湿気的な問題に着目した研究は少なく, 赤坂ら 5 が 小屋裏の強制換気による排熱排湿効果について実験的検 討を行なっている。床下についてはいくつも報告がな されており，例えば永峰・土屋 ${ }^{6)}$ は木造実験住宅と地盤 の水蒸気発生モデル箱を用いて床下の結露性状の測定を 行なっている。また水谷・宮野ら ${ }^{7)}$ は実際の木造住宅を 用いて冬季における床下換気口と地盤防湿シートの効果 について実測している。さらに葛西ら ${ }^{8)}$ は寒地の木造住 宅の耐久性問題として地盤の防・調湿材の比較評価を行 なっている。しかしそのいずれもが特定された測定結果 の一例に過ぎず，一般化された特性を抽出するのが困難 である。

本研究では, 小屋裹と床下空間の合理的な防湿設計法 を確立することを目的として，まず小屋裏・床下におけ る熱・湿気的な現象の実態を把握するために，実験住宅
を用いて長期の温湿度環境の測定を実施した99,10),11)。 これらの実测データの統計的整理に基づいて，年間変動 の特性, 日变動の特性等の把握を行なって, 防湿設計の 基礎資料としてこれら空間の熱・湿気的な特徵の抽出を 試みた。これらの測定は解析の対象に用いるデー夕を得 ることを目的の 1 つとしている。

\section{2. 実験の概要}

\section{1 実験住宅}

滋賀県栗太郡栗東町に建設された 2 棟の鉄骨系実験 住宅を用いて実測を行なった。住宅は $4 \mathrm{~m} \times 4 \mathrm{~m}$ の平屋 であり，居室とその上下に小屋裏と床下を持つ。基準仕 様の住宅を $\mathrm{A}$ 棟と称し, B 棟と称す別棟には小屋裹に 換気口があり，床下地盤に防湿シートが施工されてい る。建物の概要を図一 1 に示す。

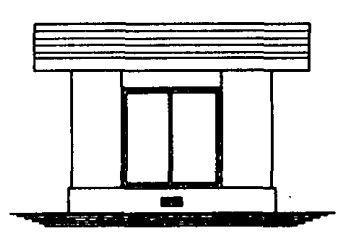

(1)南立面図

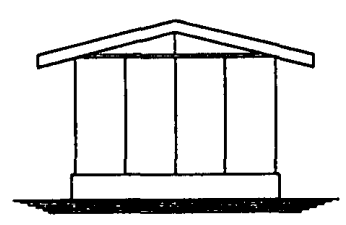

(2)西立面図

図 - 1 建物の概要
* 積水八ウス総合住宅研究所 G.L. ·工修

** 神戸大学工学部建設学科 教授. I博
Chief Engineer, Institute of Building Science, Sekisui House, M. Eng. Prof., Dept. of Architecture and Civil Eng., Kobe Univ., Dr. Eng. 
屋根は 2.5/10 勾配の切妻である。小屋裏は, $\mathrm{A}$ 棟 には特別の換気口は無いが， B 棟には東西の妻面に $190 \times 45 \mathrm{~mm}$ の小さ目の換気口が設置されている。これ は小屋裹容積が小さい故に，予備実験によると換気量が 過大となり過ぎるため，開口面積を減少させた。天井は 防湿層付きの袋入り断熱材を並べただけの状態である。

床下には A，B 棟ともに南北の基礎部分に $270 \times$ $170 \mathrm{~mm}$ の換気口が設置されている。B 棟の床下の地盤 表面には $0.5 \mathrm{~mm}$ 厚のポリエチレン・シートを敷設し， シートの継目や束周りにはテープで目止めを行ない，上 面に $10 \mathrm{~mm}$ 程度の盛土を施した。

本実験住宅は一般鉄骨住宅の部材を用いて小規模に 建てたものであるが，小屋組として $87 \times 87 \times 4000 \mathrm{~mm}$ $\times 5$ 本の母屋があり, 床下では $87 \times 87 \times 4000 \mathrm{~mm} \times$ 5 本の大引と $87 \times 87 \times 400 \mathrm{~mm} \times 9$ 本の束がある。材 質はいずれも米栂であり，無塗装。無仕上げである。

居室には出入口を兼ねて南面に $2 \mathrm{~m} \times 1.8 \mathrm{~m}$ の掃出し 空があり，日射の影響を軽減するために日射遮蔽フィル ムを貼付した。実験用の住宅なので，ビニルクロス等の 内装仕上げは施していない。

\section{表 -1 建物仕様一覧}

\begin{tabular}{|c|c|c|c|}
\hline & A & 棣 & 槽 \\
\hline \multirow{4}{*}{ 屋根 } & \multicolumn{2}{|c|}{2.5 寸勾配切妻阮べ자仕様 } & 2.5寸勾配切妻力ラー・자仕様 \\
\hline & 汃我水 & $4.5 \mathrm{~mm} \times 2$ 重 & $4.5 \mathrm{~mm} \times 2$ 重 \\
\hline & 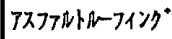 & 2居 & TXフフルトRースイング \\
\hline & 野地板 & 合板 $12 \mathrm{~mm}$ & 合板 $12 \mathrm{~mm}$ \\
\hline \multirow[t]{2}{*}{ 天井 } & \multicolumn{2}{|c|}{ 防湿局付） } & \multirow{2}{*}{$\begin{array}{ll}\text { 口ックウーネ（防湿居付） } & 50 \mathrm{~mm} \\
\text { 石西ボード } & 9 \mathrm{~mm}\end{array}$} \\
\hline & 石酸ボード & $9 \mathrm{~mm}$ & \\
\hline \multirow[t]{2}{*}{ 献废 } & \multicolumn{2}{|l|}{ ケイカル } & ケイカル板 \\
\hline & \multicolumn{2}{|l|}{ パネル } & 外壁八 \\
\hline \multirow[t]{3}{*}{ 外壁 } & \multirow{3}{*}{\multicolumn{2}{|c|}{ 妻壁 モエ决价゙ イング }} & \multirow{3}{*}{ 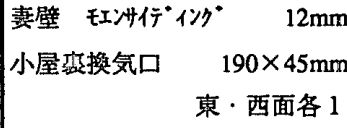 } \\
\hline & & & \\
\hline & & & \\
\hline \multirow[t]{2}{*}{ 内壁 } & \multicolumn{2}{|c|}{ 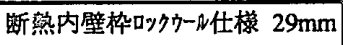 } & \multirow{2}{*}{ 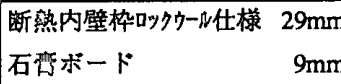 } \\
\hline & 石敨ボード & $9 \mathrm{~mm}$ & \\
\hline \multirow[t]{2}{*}{ 床 } & \multicolumn{2}{|r|}{$5.5 \mathrm{~mm}$} & \multirow{2}{*}{\begin{tabular}{|lr} 
合板 & $5.5 \mathrm{~mm}$ \\
床パネル & $12 \mathrm{~mm}$
\end{tabular}} \\
\hline & 床パネル & $12 \mathrm{~mm}$ & \\
\hline 底下 & \multicolumn{2}{|c|}{ 防湿シート 無し } & 防湿シート+盛土 \\
\hline \multirow{3}{*}{ 基碱 } & 平屋用基䃈 & $120 \times 480 \mathrm{~mm}$ & \multirow{3}{*}{$\begin{array}{l}\text { 平屋用基硞 } \\
\text { 床下換気口 }\end{array}$} \\
\hline & 床下換気口 & $270 \times 170 \mathrm{~mm}$ & \\
\hline & & 南 · 北 & \\
\hline
\end{tabular}

天井。床の気密性を求めるために, 通気性能の実験を 行なった。JIS(案)に基づく加圧法に準じて行なった結 果, 天井 $1.713 \mathrm{~cm}^{2} / \mathrm{m}^{2}$, 床 $0.820 \mathrm{~cm}^{2} / \mathrm{m}^{2}$ の有効隟間面 積を示した。また，小屋裏と壁体内空間とはつながって いるが，床下と壁体内とはゴムパッキングを用いて遮断 構造になっている。
屋根・床・外壁等の仕様を表一 1 に示す。

\section{2 測定の概要}

小屋轰と床下の仕様を変えた 2 棟の住宅におい て, 室内の温湿度環境と外界の気候変動に関する長 期 (1987.12 1989.3) にわたる連続測定を行なった。

温度測定には $\mathrm{T}(\mathrm{CC})$ 熱電対の $0.2 \mathrm{~mm} \phi$ を用いて，小 屋裏・居室・床下の上中下空気温や各種の表面温など 63 点を測定した。湿度測定には $\mathrm{S}$ 社製の電気抵抗型湿 度センサを用いて，温度に対応する空間を 24 点測定し た。その他，日射量・放射収支量・風向・風速・降雨 量等について自動計測した。測定間隔は 30 分を標準と した。

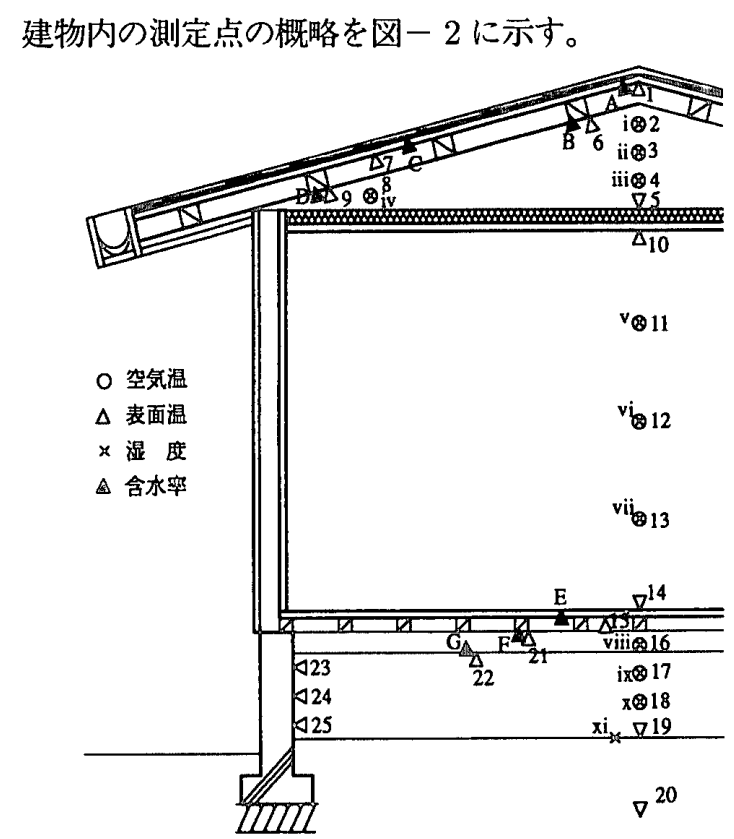

図-2 建物内の測定点

\section{3 実験の種類と条件}

実験は外界気像条件と住宅との最も単純な関係を 把握するために，居室に暖冷房のない自然状態につい て一年間測定を行なった。さらに，居室の暖房・加湿 を全日で行なった場合について，冬季約 1 ケ月間の実 験も行なった。暖房は電気ヒータを $20^{\circ} \mathrm{C}$ 設定で $\mathrm{ON}$ OFF 制御し，加湿は超音波加湿器を $50 \%$ 設定で同じく ON-CFF 制御を行なった。

\section{4 湿度センサの較正}

測定を実施する際に，計測器類の精度の検定は重要 である。特に湿度センサの場合, 計器本来の誤差に加之 て長期間使用したときの劣化の問題，さらに温度・湿度 が同時に変動するような場合には誤差が増大する。

ここでは特に湿度センサの温度依存性について検討 する。基準器として GE 社製の鏡面冷却式露点計を用 い, 試験槽として S 社製の分流式精密湿度発生装置を 
使用した。温度は $5{ }^{\circ} \mathrm{C}$ から $55^{\circ} \mathrm{C}$ までを $10^{\circ} \mathrm{C}$ 刻みで 6 点, 相対湿度は $10 \%$ から $90 \%$ までを $10 \%$ 刻みで 9 点, 合計 54 点について試験を行なった。

結果を図ー 3 に示す。ここではセンサの全体的な傾

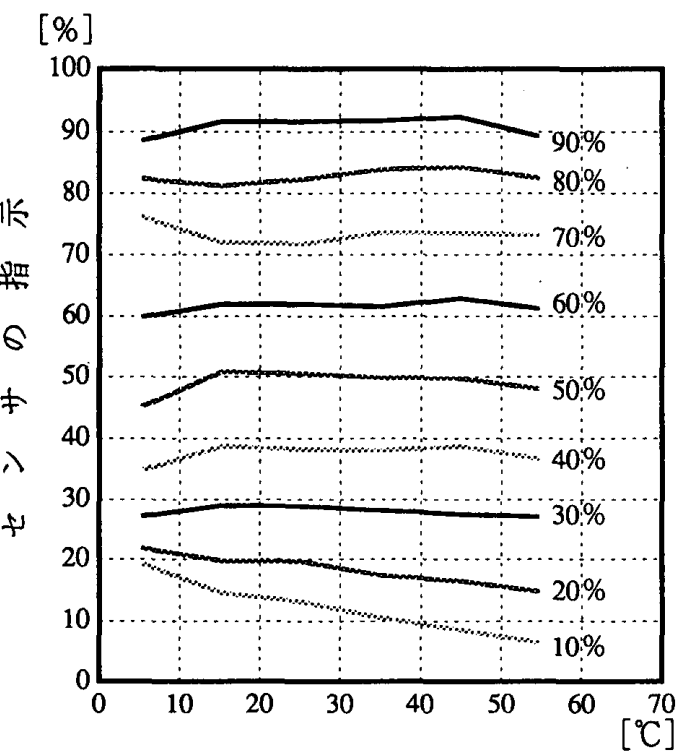

図一－湿度センサの誤差

向を知るためにデー夕は複数のセンサの平均値で示し た。横軸は温度, 縦軸は湿度センサの指示值を示し, そ れらの交点が真の相対湿度を表す。全体の傾向はさほど 明確には現れない。湿度 50\%以下の低湿状態では低温 域と高温域の両端での誤差が大きく，5１0\%もの誤差 を示す場合がある。70 80\%の高湿域では $\mathrm{S}$ 字型の変 化を示し, $30 \sim 50^{\circ} \mathrm{C}$ の中温域と $10^{\circ} \mathrm{C}$ 以下の低温域で の誤差が大きく，5\%前後の誤差を示す。

以上の愦差の結果は予想よりも大きくはなかった。し かし，これらはあくまで静的な特性の検討結果であり， 実際には動的な特性も問題となる。すなわち，例えば絶 対湿度が一定で温度のみが急に上昇したような場合，湿 度センサ内の温度補正回路の温度検出端としてのダイ オードがその熱容量のために応答が遅れて実際よりも低 温を示し，元々湿度センサは温度が低いほど高い湿度を 指示する性質があるため, 湿度センサの出力が実際より も高く表現されてしまい，変動していないはずの絶対湿 度が見かけのうえで上昇したかのように指示されること になる。これらの動的な特性は充分には把握できていな いので，ここでは測定の詥差として含まれる。

\section{3. 測定結果}

\section{1 年間の温湿度変動}

自然状態における $\mathrm{A}$ 棟の測定データの日平均値の年 間変動について，日平均の埕平均值を用いて示した。

(1) 小屋裹の温湿度変動（図-4(1),(2) 参照)

日最高值・最低值を旬平均して变動の幅を表示した。
小屋虽温度変動の幅は大きく，外気は最低平均より も少し高く推移する。小屋裹絶対湿度变動の幅も大き く，外気も最低平均よりも少し高いレベルにある。

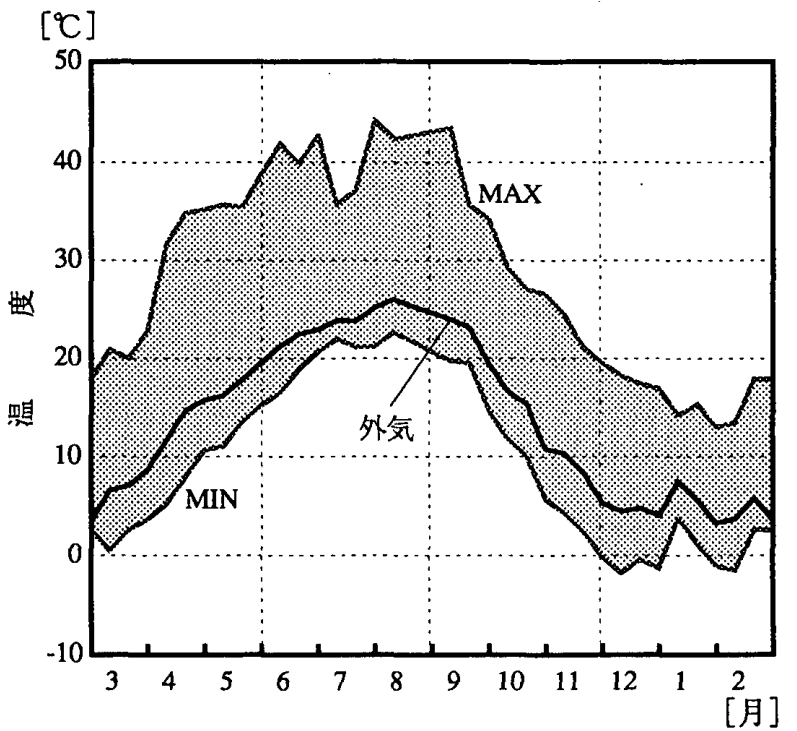

$\left[\mathrm{g} / \mathrm{kg}^{\prime}\right]$

図－4(1) 小屋裏温度の年間変動

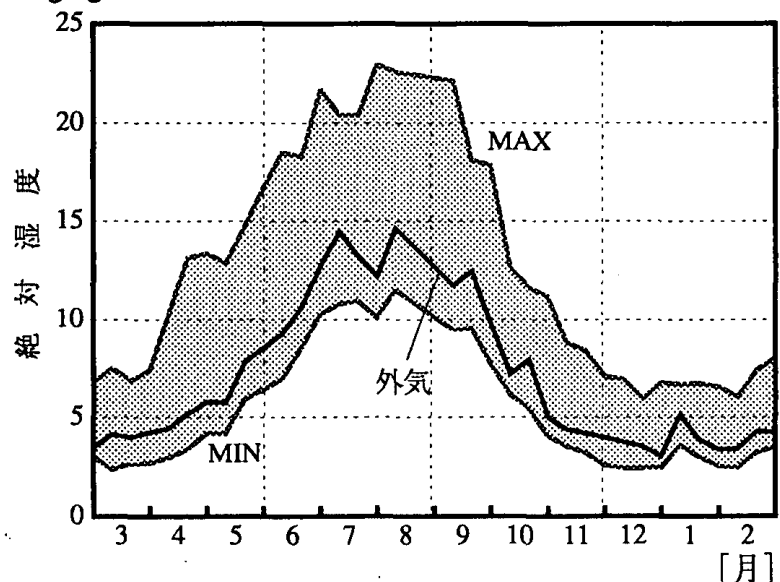

図-4(2) 小屋裏絶対湿度の年間変動

（2）床下の温湿度変動（図一 $5(1),(2)$ 参照）

床下温度変動の幅は大きくない。外気は春季から夏 季にかけては最高・最低の中間值を取るが，秋季から冬 季には最低值にほほ同様の值を示す。床下絶対湿度变動 の幅は温度の場合より少し大きい。外気の絶対湿度は春 から夏には最高・最低の中間にあるが，秋から冬には最 低值にほほ等しい。

(3) 小屋裹換気の影響 (図一 $6(1),(2)$ 参照)

年間で換気口有無の差を見てその効果を検討する。 小屋裹温度はほとんど差が少ない。これは換気口が 小さい故にその効果も顕著には表れていない。小屋裹 絶対湿度は年間を通して換気口のある方が低い目の值を 取る。ここでの換気口は温度より湿度に対して効果が ある。

(4) 床下防湿の影響 (困一 7(1),(2) 参照) 

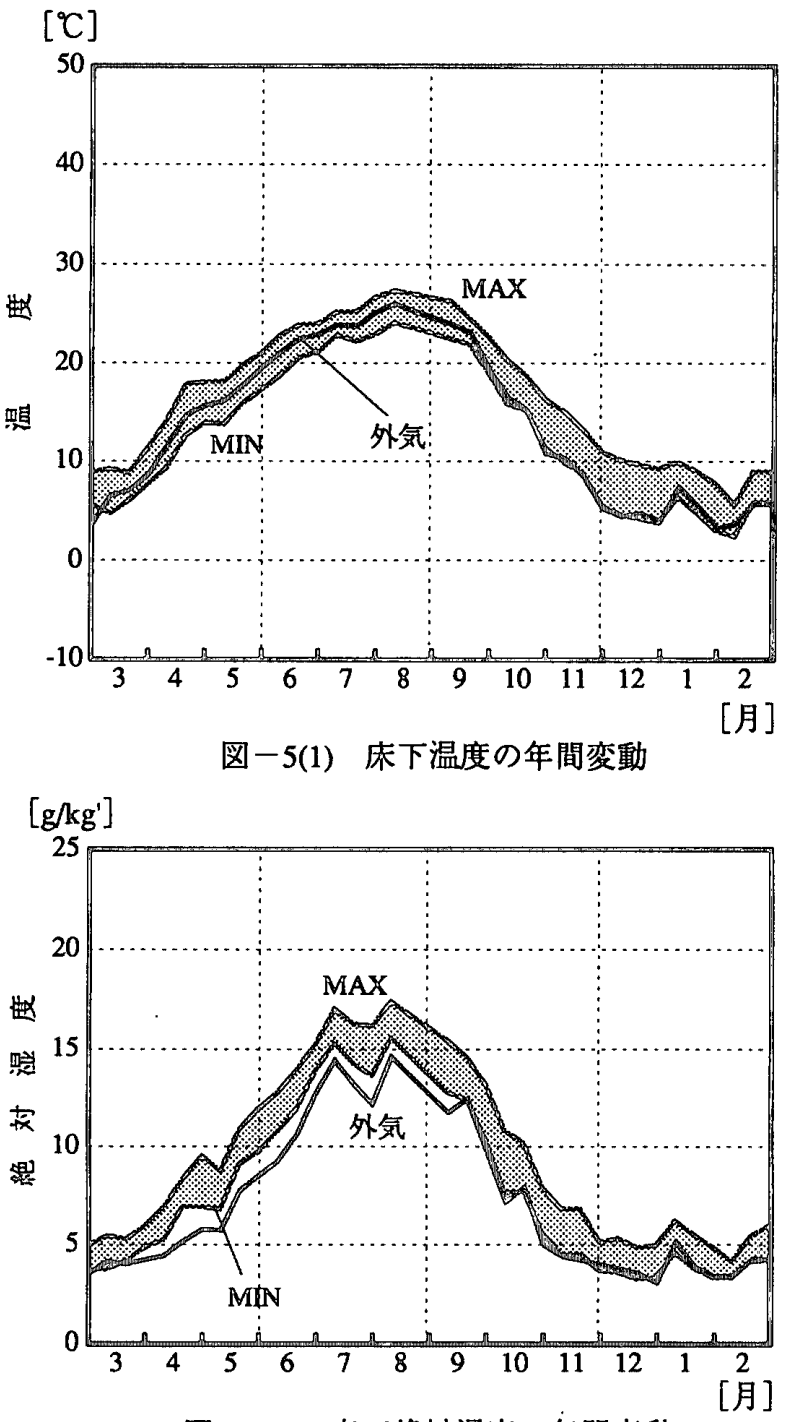

図-5(2) 床下絶対湿度の年間変動

年間で床下防湿シート敷設の効果を見る。

床下温度差はほとんど表れない。床下絶対湿度は夏 李（6月中旬 8 月中旬）に，防湿シート有りの方が高 湿となっており，その他の季節は防湿シートのある方が 湿度は低い。

\section{2 李節別の温湿度変動}

季節ごとの代表的な 1 週間のデー夕を取出し，基準 仕様としての A 楎の测定結果を示す。

(1) 冬季の温湿度変動 (困-8(1),(2),(3) 参照)

小屋裏空間温度は昼間，屋根面に受熱する日射の影 響で外気温よりも高くなるが，夜間は逆に屋根面から大 気への夜間放射による冷却によって外気温よりも低くな る。小屋裏の相対湿度は $45 \sim 85 \%$ の範囲で日変動する。 絶対湿度で比較すると，小屋裏が昼間，外気よりも相当 高く，夜間，外気より低い傾向が極めて顕著に現れる。 これは昼間の気温上昇と日射による急激な屋根面の加熱 $\left[{ }^{\circ} \mathrm{C}\right]$

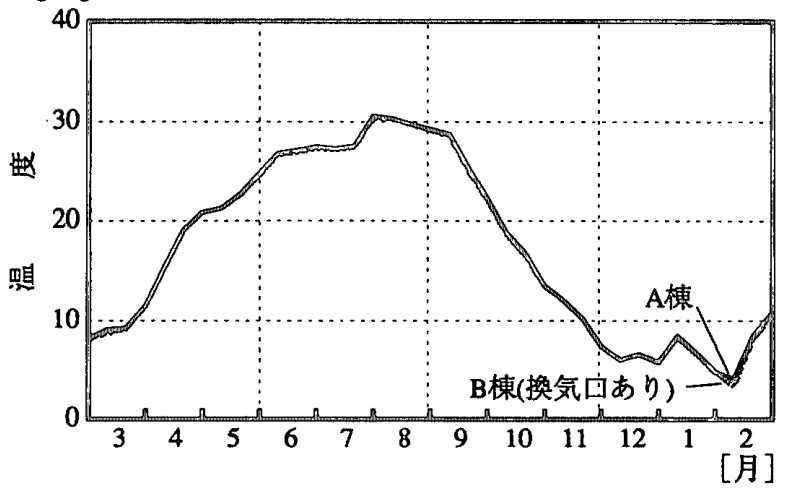

図一6(1) 小屋稁換気口の有無による温度变化

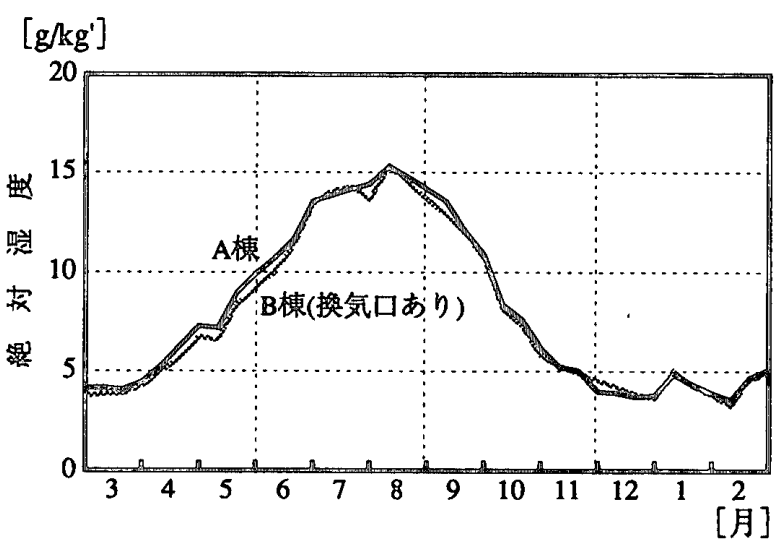

図一6(2) 小屋裏換気口の有無による絶対湿度变化

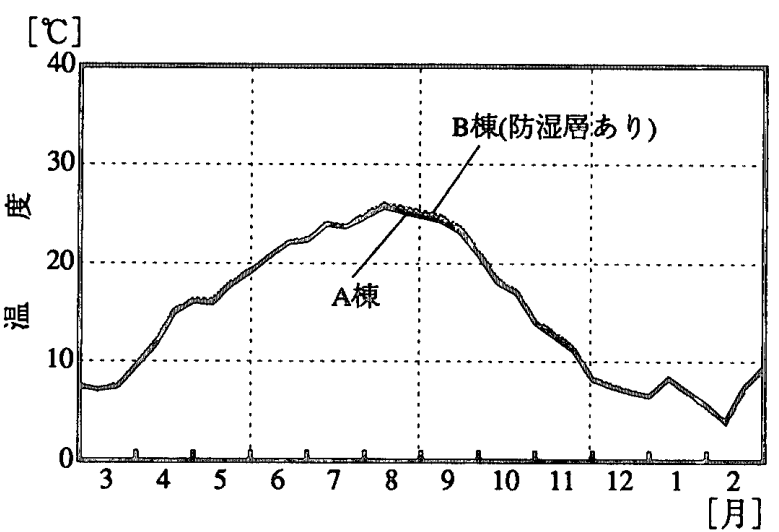

図一7(1) 床下防湿の有無による温度変化

とによって，野地板から小屋裹への放湿現象によるもの と考えられる。また夜間は，逆に気温降下と夜間放射に よる屋根面の冷却とによって, 野地板へ水分が吸湿され ることによる小屋裏湿度の低下が生じる。以上によって 小屋裏湿度に及ほす野地面等の吸放湿効果は極めて大き いことが分かる。

床下空間温度は外気温より高いレベルにあり，且つ 日変動している。これは本実験住宅特有の原因と考えら れ，南面の掃出し空（日射遮蔽フィルム貼り）を通して 透過する日射の影響で床表面温度が上昇し，床の断熱性 が小さい故に影響を直接的に受け，それによって床下空 間温度も変動する。床下の相対湿度は 70 85\%程度で 


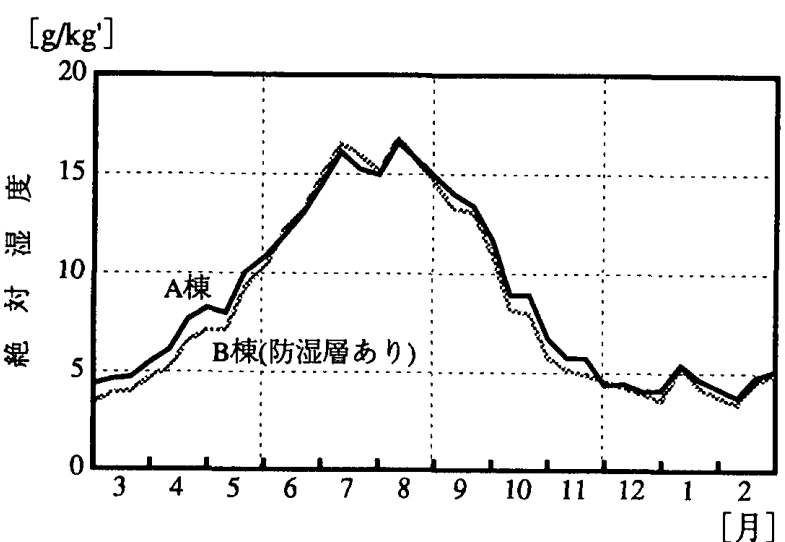

図ー7(2) 床下防湿の有無による絶対湿度変化

あまり大きな変動ではない。床下の絶対湿度は高く外気 以上であり, 変動のパ夕ーンは温度の場合と似ている。 これらの現象は床面合板の日射受熱による放湿と，床下 温度が上昇したことによる地盤面がらの放湿によって 生じると考えられる。
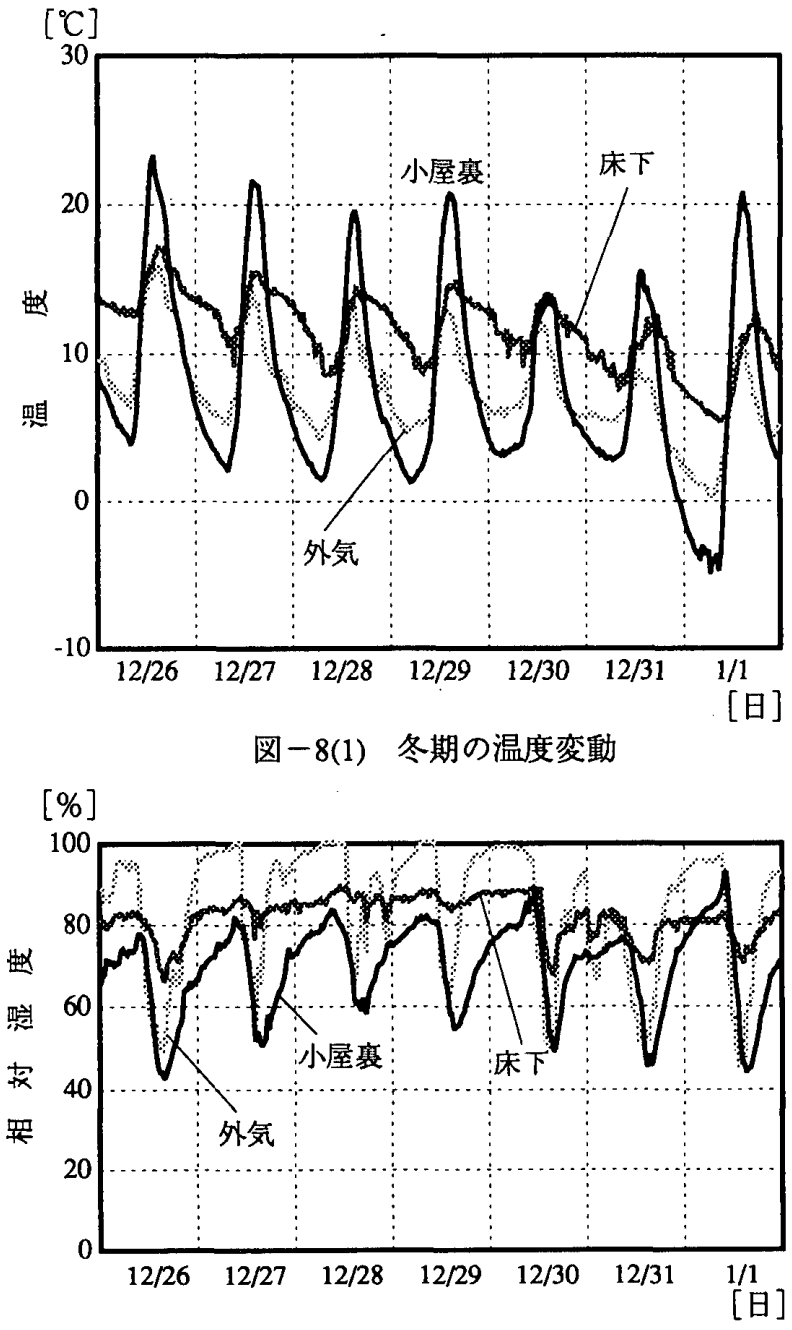

図-8(2) 冬季の相対湿度変動

(2) 暖房期の温湿度変動 (図一 $9(1),(2),(3)$ 参照)

居室が暖房加湿され, 温度が $17 \sim 20^{\circ} \mathrm{C}$ に, 湿度が 45〜50\%（6〜7g/kg'）に制御された状態での測定結果

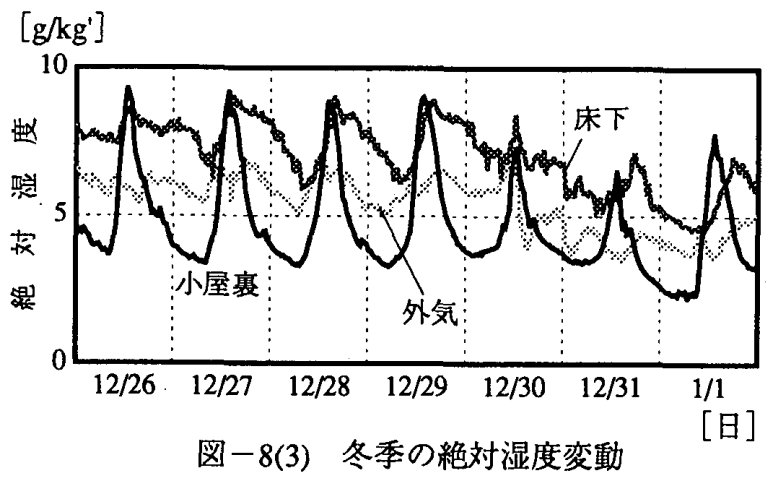

について検討する。

小屋哀温度は，通常は外気温と居室温との中間の値 を示すはずであるが，昼間，暖房された居室より $4^{\circ} \mathrm{C}$ 程度も上回ることがあり, 夜間に外気温を若干下回るこ ともある。小屋裹の相対湿度は 40〜 75\%の幅で日変動 する。小屋裹の絶対湿度は単純に居室と外気との間には なく，昼間に居室よりも高くなることがあり，また夜間 に外気より若干低くなる傾向を示す。これは居室から小 屋裹への水分供給よりも，前項で示した野地板からの吸 放湿効果の方が影響の大きいことを示している。

床下温度は居室暖房の影響で比較的一定温度になっ ている。床下の相対湿度は 45〜70\%程度の日変動をす る。床下の絶対湿度は居室からの加湿によってかなり高 いレベルにあり，自然状態の場合と比較すれば変動の幅 が温度と同様に少なくなっている。

(3) 夏季の温湿度変動（図一 10(1),(2),(3) 参照)

小屋裹温度はかなり高温まで上昇し， $50^{\circ} \mathrm{C}$ を超え る日もあり, 変動の幅も大きい。小屋裏の相対湿度は $25 \sim 70 \%$ 程度の日变動をする。小屋裹の絶対湿度は温度 変化に応じて大きく変動する。野地板からの放湿現象に より $28 \mathrm{~g} / \mathrm{kg}^{\prime}$ 程度まで上昇する。

床下温度も外気温よりは小さいが最大 $5^{\circ} \mathrm{C}$ 幅程度で 日変動する。床下の相对湿度は $60 \sim 85 \%$ 程度の日変動 をする。床下の絶対湿度もかなり高く， 18g/ $/ \mathrm{kg}^{\prime}$ 程度に もなって外気よりも高いレベルにある。

\section{3 季節別平均值の日変動}

変動のゆらぎ成分を除いて平均値な特性を抽出する 目的で，温湿度の際立った季節ごとに約 1ヶ月間の測定 データの時刻別の平均值を求め，1 日の変動で A 棟, $\mathrm{B}$ 棟の比較を示す。

(1) 夏季平均值の日変動 (図一 $11(1),(2)$ 参照)

小屋裏の温度は $\mathrm{A}$ 棟， $\mathrm{B}$ 棟の差があまり大きくない。 小屋裏の絶対湿度は B 棟の方が日中から夕方にかけて 低く，夜間から午前中は逆転する。これは B 棟の小屋 裏換気口による外気との換気の影響で，昼間は除湿さ 

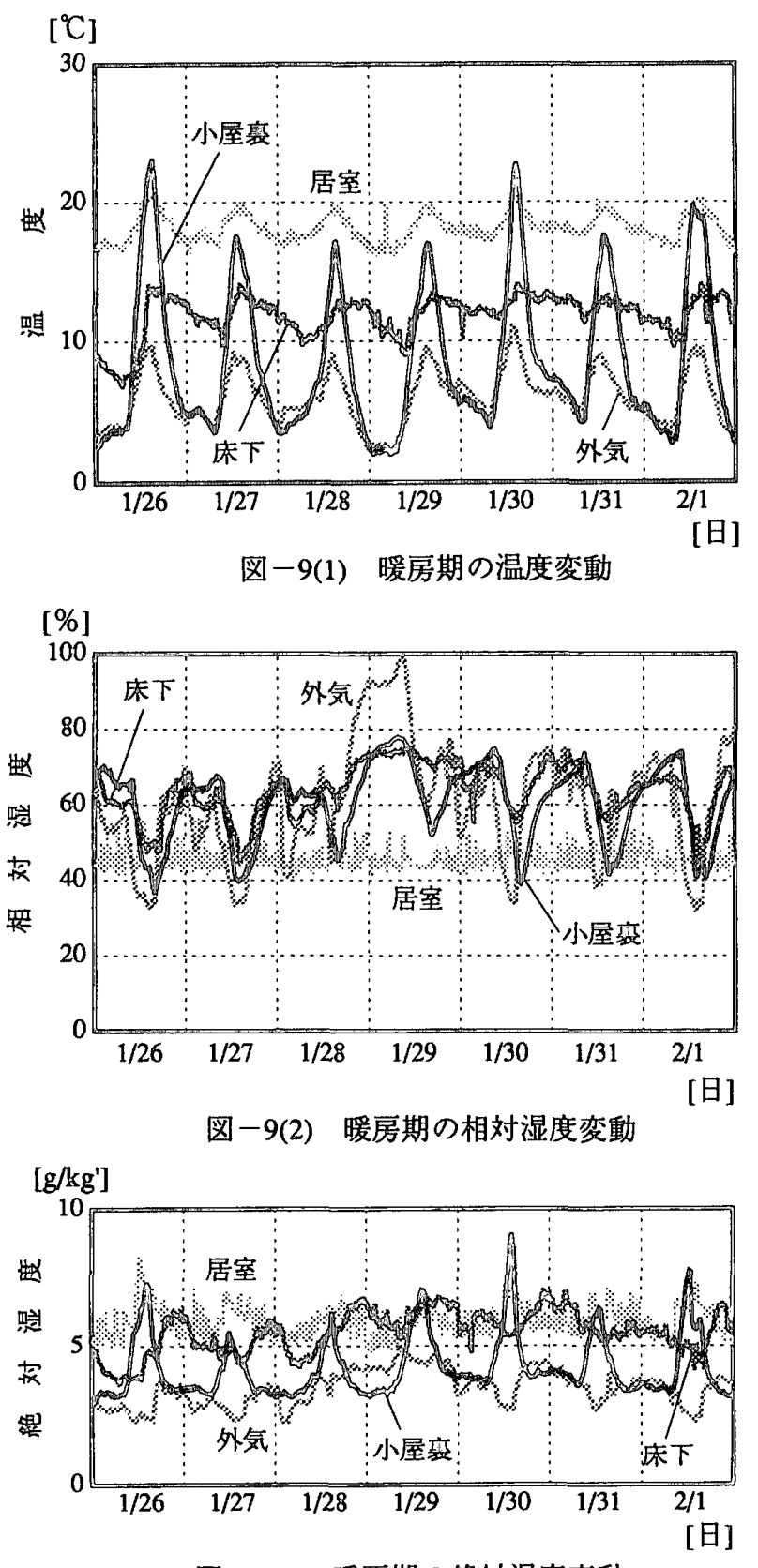

図-9(3) 暖房期の絶対湿度変動

れ，夜間，小屋裏より高い外気によって加湿されている ことになる。

床下の温度は変動の幅が小さく, A 棟, B 棟の差も 少ない。床下の絶対湿度はほとんど一定で， $\mathrm{B}$ 桠の方が 高い。これは高湿な床下空間から地盤面への水分の移動 (地盤の吸湿現象) が, B 植では防湿シートによって阻 害されたため，と考えられる。

(2) 冬季平均值の日变動 $($ 図-11(1),(2) 参照)

小屋裹の温度は $\mathrm{A}, \mathrm{B}$ 槽の差が少ない。小屋裏の絶 対湿度は午後から夕暮にかけて $\mathrm{B}$ 横の方が低い。これ は換気による除湿効果である。

床下の温度は変動の幅が小さく, $\mathrm{A}, \mathrm{B}$ 棟の差も少な い。床下の絶対湿度はほとんど一定で，B 棈の方が低
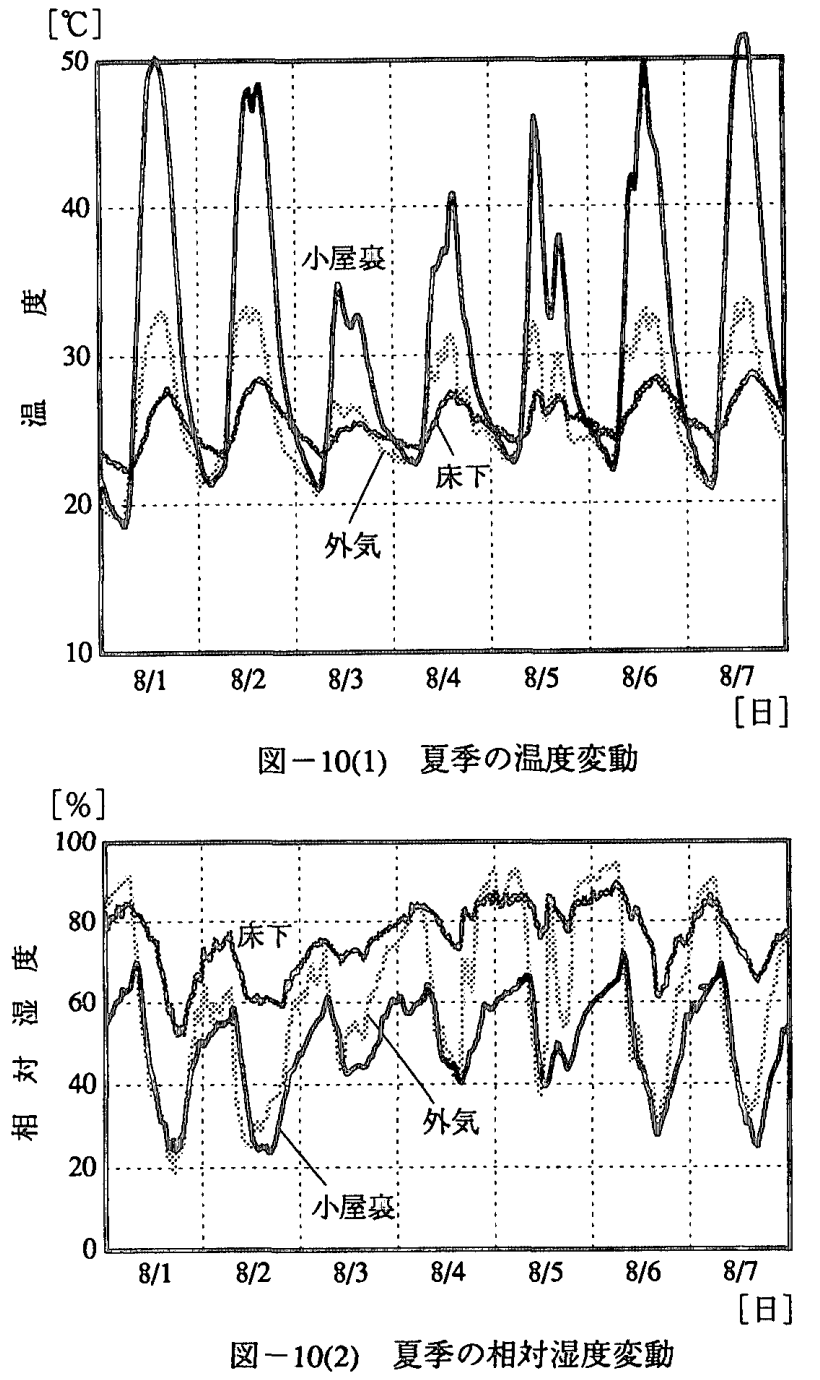

い。これは地盤面から乾燥した床下空間への水分の移動 (地盤からの放湿現象) が，B 棟では防湿シートによっ て妨げられた故と考えられる。

（3）暖房期平均值の日変動（図-12(1),(2) 参照）

小屋蔉の温度は $\mathrm{A}, \mathrm{B}$ 棟の差が少ない。小屋稟の絶 対湿度は $\mathrm{B}$ 棟の方が日中かなり低い。これは換気の効 果である。

床下の温度は $\mathrm{A}, \mathrm{B}$ の差が少ない。床下の絶対湿度 は $\mathrm{A}$ 棟が高くなり，B 棟の方がかなり低くなった。こ れは居室暖房によって床下空間も温度が少し上年した 結果, 地盤からの水分供給が促進され，地盤防湿の効果 がより顕著に出た結果である。

(4) 梅雨期平均値の日変動. (図-13(1),(2) 参照)

小屋赛の温度は $\mathrm{A}, \mathrm{B}$ 棟の差が少ない。小屋寨の絶 対湿度は B 棟の方が日中かなり低い。これは換気の効 果である。

床下の温度は A, B の差が少ない。床下の絶对湿度 はほとんどー定で，A，Bの差も少ない。 

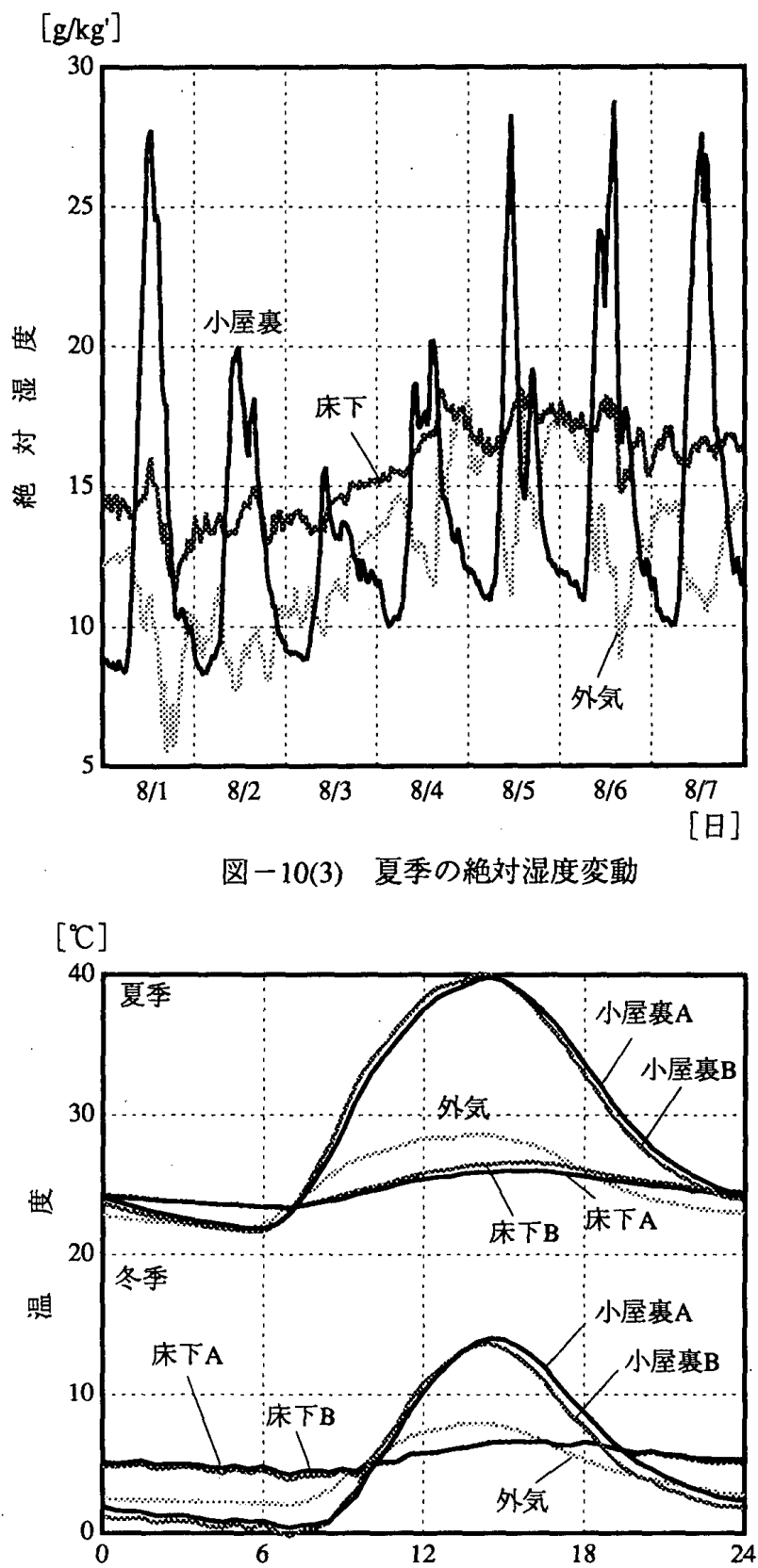

図-11(1) 夏季・冬季の平均温度の日変動

\section{4 上下の温湿度分布}

極端期 1 ケ月間の測定データを時刻別に平均した值で 1 日の変動を A 棟の結果で示す。

(1) 小屋裏温湿度分布 (図一 14(1),(2) 参照)

温度は夏季，冬季ともに上下差は大きくない。絶対 湿度は夏季の日中に大きな分布が生じる。これは屋根面 の日射受熱によって急激に加熱された野地板から小屋 襄への放湿現象による影響である。

(2) 床下温湿度分布 (図一 15(1),(2) 参照)

温度は夏季・冬季ともに若干上部の方が高い。しかし 絶対湿度はほとんど差が少なく，夏季にわずかに下部近 傍の方が高い。

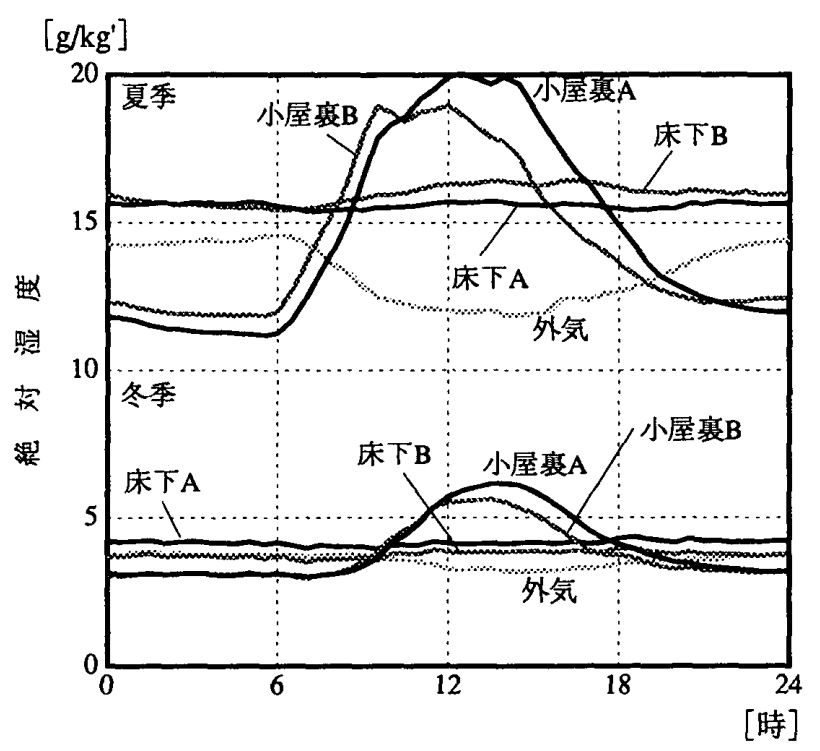

図-11(2) 夏季・冬季の平均絶対湿度の日変動

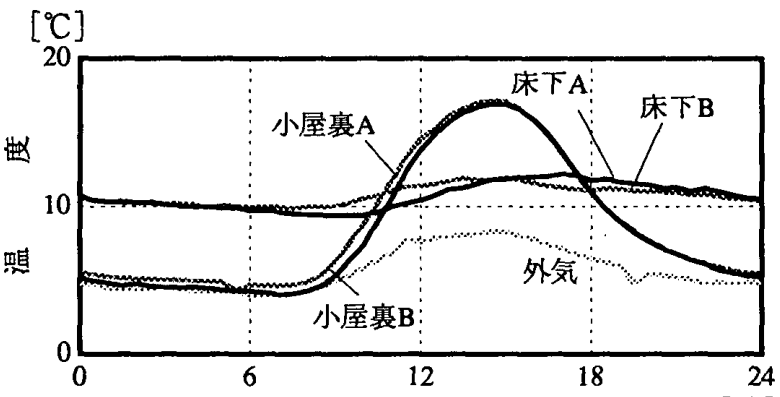

図-12(1) 暖房期の平均温度の日変動

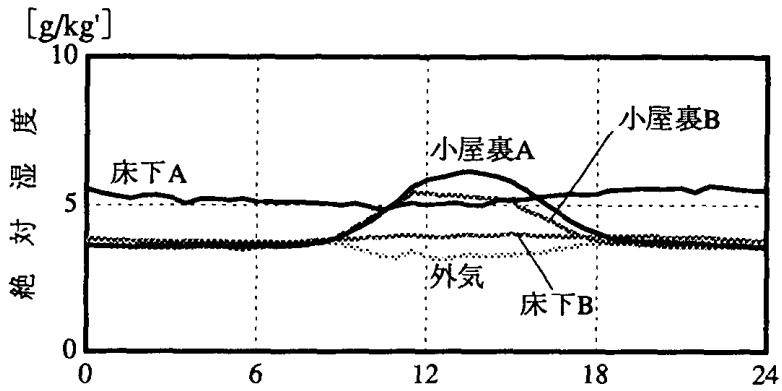

図-12(2) 暖房期の平均絶対湿度の日変動

3.5 表面結露の判定（図一 16(1),(2) 参照)

(1) 小屋裹結露

小屋裹空気の露点温度と野地板表面温度との関係を 冬季 1ヶ月間の測定データで示す。

午前中の温度上昇時に小屋裹露点温度と野地板表面 温度が重なって結露の伦険性を生じているようにも見え るが，実際には最小でも $2 \sim 3^{\circ} \mathrm{C}$ 野地温度の方が高く， 結露域には達していない。

(2) 床下結露

床下空気の露点温度と地表面温度との関係を夏季 1ヶ 月間の測定データで示す。床下空間の露点温度の方が 

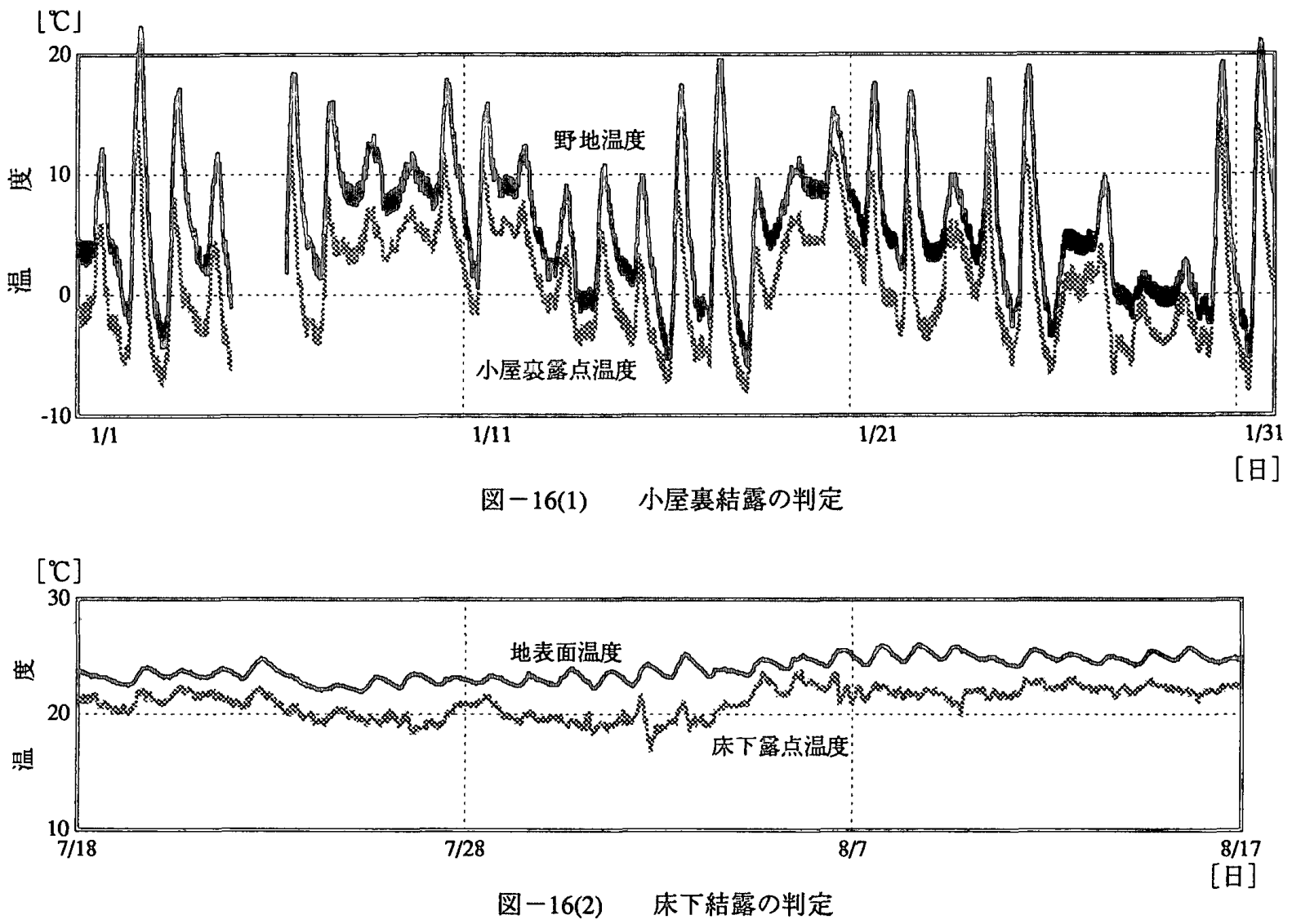

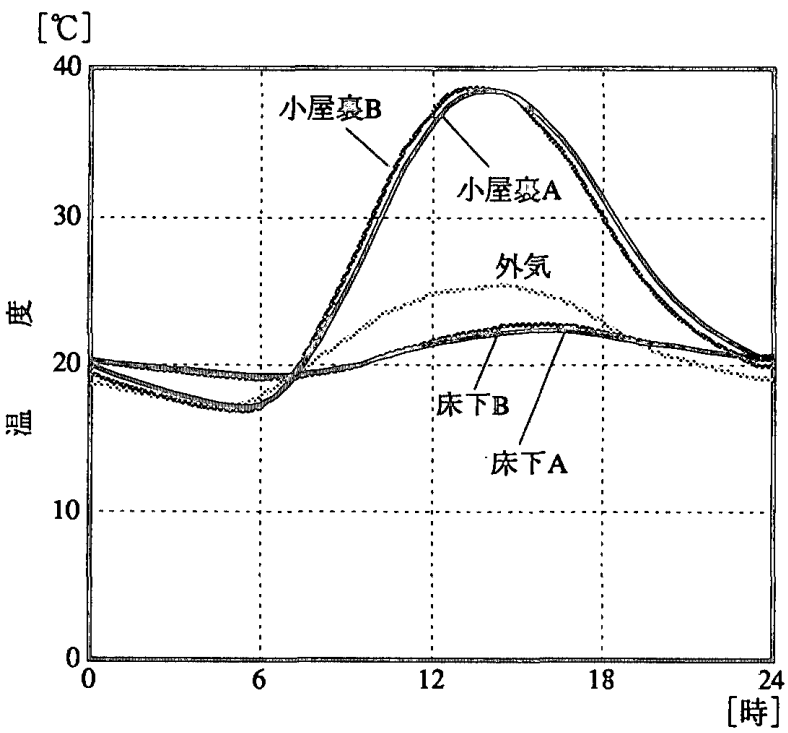

図－13(1) 梅雨期の平均温度の日変動

地表面温度よりかなり高く，地表面での夏型結露はこの 場合発生していない。

\section{4. 齐とあ}

実験住宅において小屋裏と床下に関する温湿度の 長期测定を行なった結果，次のようなことが明らかと なった。

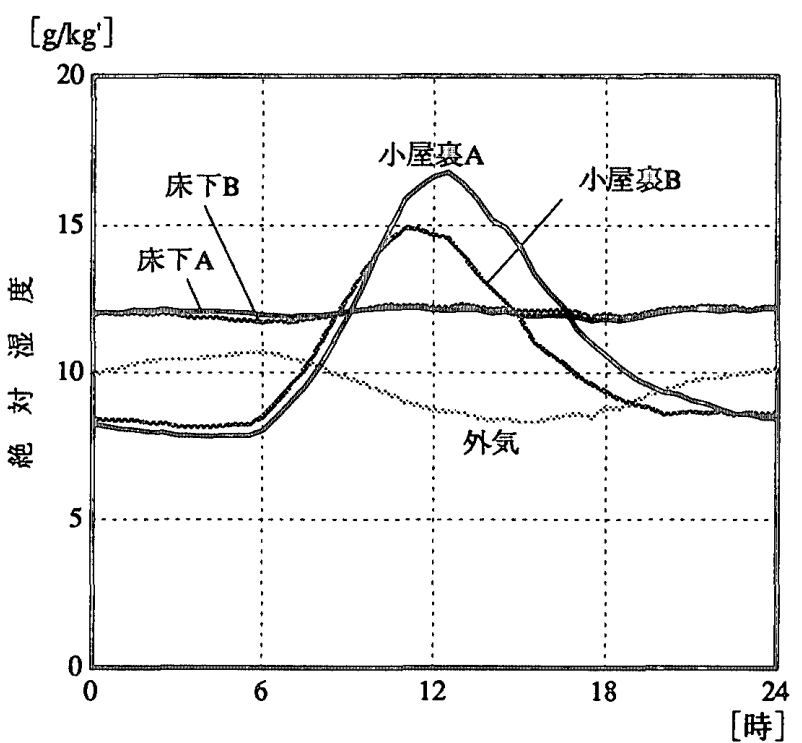

図-13(2) 梅雨期の平均絶対湿度の日変動

\section{1 小屋裹空間}

（1）小屋裹空間では，昼間の日射受熱と夜間の放射冷 却とによって大きな温度の日変動を生じ，それに応じて 絶対湿度も大きく変動し，外気のそれよりも大きい。湿 度变動の原因は野地板からの吸放湿現象によるものであ ク，その影響は大きい。

（2）居室か暖房加湿された場合でも，小屋裹の温湿度 は昼間に居室以上になったり，夜間に外気以下となった 
[ $\left.{ }^{\circ} \mathrm{C}\right]$

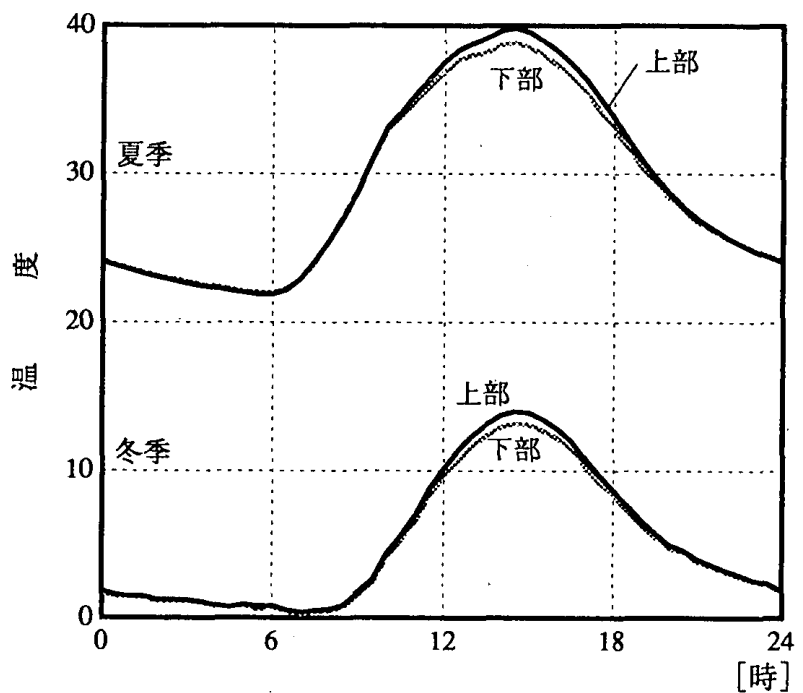

図－14(1) 小屋裏の上下温度分布

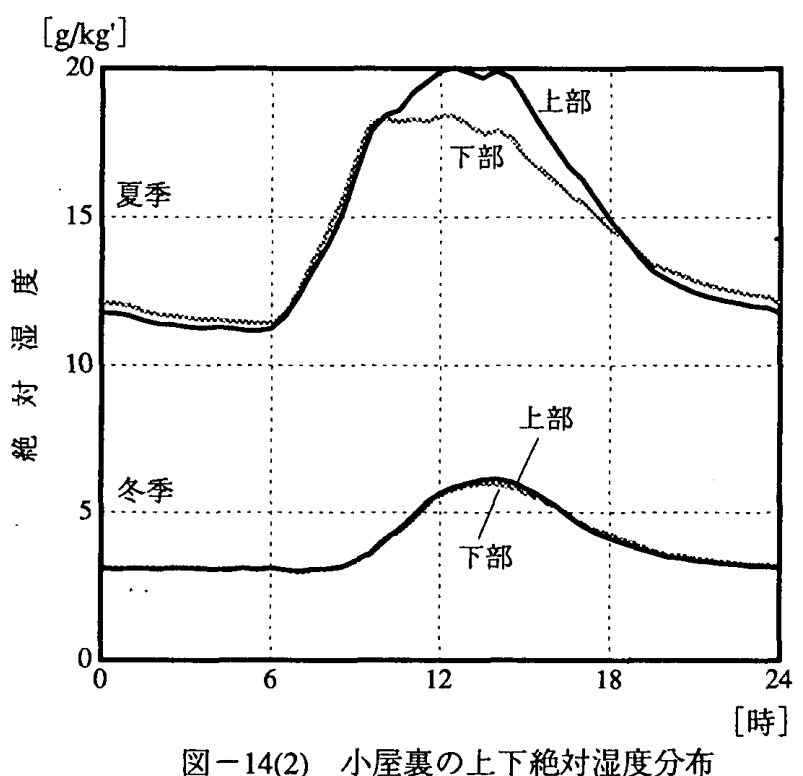

クすることがある。換気回数 4 回 $/ \mathrm{h}($ 風速 $1 \mathrm{~m} / \mathrm{s}$ ) 程度の この実験住宅の場合でも，小屋裹では居室よりも外界の 影響の方が大きく作用することを示した。

（3）平均的な日変動パターンをみると，換気口が有る ことによって小屋裏の絶対湿度は日中低く，夜間と午前 中には逆に高くなる。これは昼間は外気によって除湿さ れ，夜間は小屋裏より高い外気によって加湿されている ことを意味する。

（4）小屋裏の絶対湿度の上下分布は夏季の日中に上部 が高くなっているが，これは夏季の大きな日射に基づく 野地板からの放湿によるものと考えられる。

\section{2 床下空間}

（1）床下に防湿シートを敷設すると，結露の危険性が 高い夏季に床下空間がやや高湿となっている。

（2）居室か暖房加湿された場合に，床下空間では居室
[C]

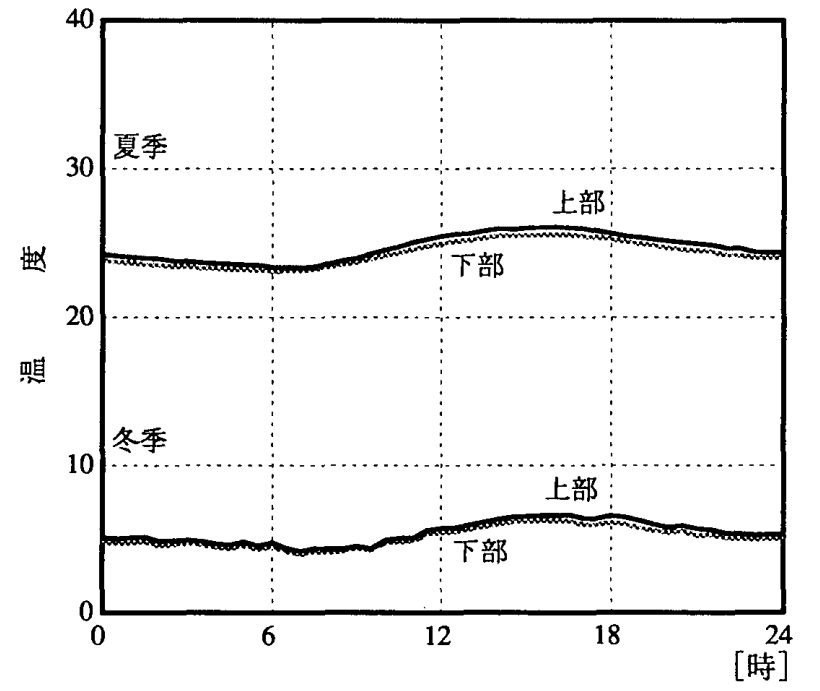

図-15(1) 床下の上下温度分布

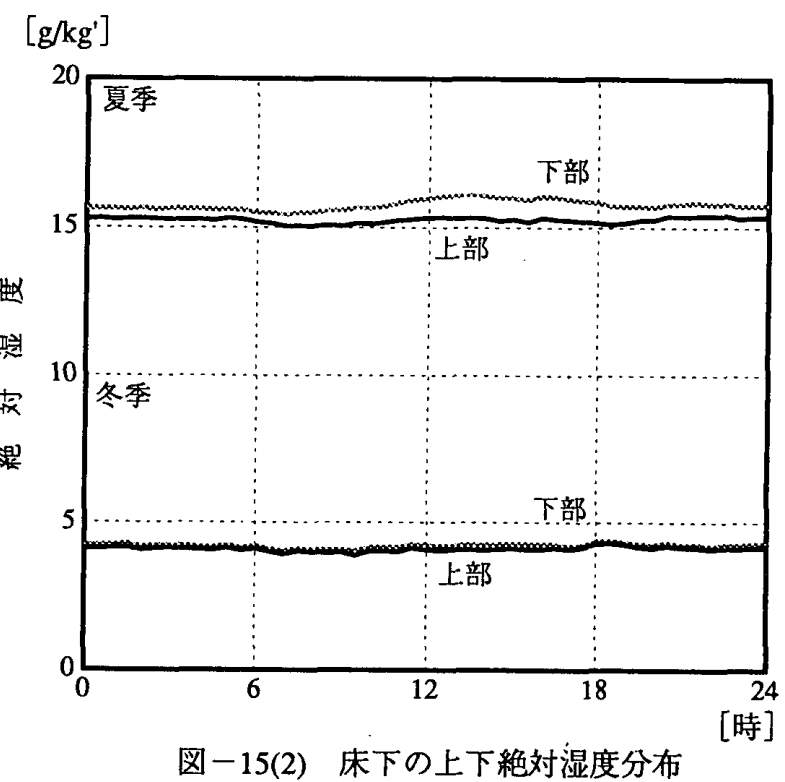

の影響を受け温湿度とも比較的一定でかなり高くなって いる。

（3）平均的な日変動パターンで床下の絶対湿度をみる と，ほとんど日変動せずに一定で，防湿シートがある 場合，夏季にはやや高湿となり，冬季には逆に低湿とな る。これは夏季には防湿シートによって床下空間から地 盤面への水分の移動が阻害されていることを意味する。

（4）床下の絶対湿度の上下分布は下部の方がやや高い。 なお，小屋淾および床下空間における温湿度の挙動 については，別稿にて数値解析に基づき改めて詳細に検 討する。

\section{参考文献}

1）松本 衛, 石田武司：小屋裏の結露防止に関する研究一 吸放湿材の効果一，日本建築学会近畿支部研究報告集・ 部画系, pp.21 24, 1987.5 
2) 松本 衛, 林部則彦：床下灴間の熱湿気性状, 日本建筑 学会近畿支部研究報告集・計画系, pp.89 92, 1989.5

3) 松本 衛, 妹尾朋計：地盤を考慮にいれた床下の湿気 性状解析, 日本建築学会近畿支部研究報告集-計画系, pp.97 100，1991.5

4) 松本 衛, 橋本 猛: 床下の防湿設計に関する研究一地 盤水分を考虑した床下の温・湿度解析一, 日本建築学会 近畿支部研究報告集・計画系, pp.133 136, 1992: 6

5) 赤坂 裕, 黒木荘一郎, 小原聡司：小屋裏強制換気に上 る排熱効果に関する実験的研究（その2）小屋裹強制換 気量が大きい場合, 日本建築学会大会学術講演梗概集 D, pp.581 582, 1990.10

6) 永峰 章, 土屋喬雄：建物の断熱構造化と結簬防止に関 する研究 (その 1) 〜 (その 5), 日本建築学会大会学術 講演梗概集 D， 1983 1987

7）水谷章夫，宮野秋彦，大澤徽夫：住居の床下空間の防湿 に関する研究 (第 1 報) (第 2 報), 日本建築学会大 会学術講演梗概集 D, pp.959 962，1987.10

8）葛西英夫, 西川 忠, 高島正秀: 床下環境の改善に関する 実験的研究 (その 5 ) 材料別防湿性能比較実験, 日本建 築学会大会学術講演梗概集 A, pp.757 758, 1990.10

9) 松本 衛, 宮田靖久: 小屋裏の湿度变動に関する研究 (そ の 1）モデル住宅における実測とその解析，日本建築学 会近畿支部研究報告集・計画系, pp.189 192，1988.5

10）松本 衛, 宮田靖久：小屋裹の湿度変動に関する研究 (その 2) 壁体吸放湿効果の検討，日本建築学会近畿支部 研究報告集・計画系, pp.81 84, 1989.5

11）宮田靖久：住宅の小屋裹と床下空間の温湿度特性，日本 建築学会環境工学委員会熱環境運営委員会第 21 回熱シ ンポジウム, pp.139 150, 1991.8

\section{[Appendix］外気絶対湿度の日変動に関する袷討}

本文の図一 11(2)，図一 13(2) に示されるごとく，夏季の 外気絶対湿度が昼間に低くなり，むしろ夜間に高くなってお クこれはこれまでの通説としての常識とは異なる現象を示し た。この原因として，1）実測を行なった地域特有の現象，2） 湿度センサの誤差，3）本現象が実際に発生，等が考えられる。

実験を行なった滋賀県栗東町の近傍で信頼できるデー夕を 収集しているのは彦根気象台であるが，栗東町からは $40 \mathrm{~km}$ 近くも離れており，しかも当時，外気の湿度デー夕は日に 4 回 （6 時間ごと）しか測定していないので，比較検討の対象とし てはあまり適切とは言い難いが，付図一 1 に示すと，彦根の 15 時のデー夕を見るとわずかではあるが下がる傾向にある。

さらに筆者の所属する研究所 (京都府木津町) において, 栗東町での実験と全く同じ条件，すなわち，百葉箱に入れな熱 電対と湿度センサで，再度外気データの測定を行なった。比 較すべき奈良地方気象台は当地の東南 $5.7 \mathrm{~km}$ にあり, 温湿度 の測定には白金抵抗温度計と塩化りチウム露点計が使われて いる。付図ー 2 によれば，木津町デー夕も本文の図ー11(2)
と同様の変動パターンを示す。また奈良気象台データと比較 すると，湿度計が異なるにもかかわらず，同様の傾向を示す。 したがって外気湿度の变動パターンが栗東町特有の現象では ないことが分かる。

また上記の測定值で外気が日最高気温を示すときの湿度セ ンサの指示がー $5 \%$ 程度の趾差を持っていたとしても, 絶対湿 度に換算すればー $1.0 \mathrm{~g} / \mathrm{kg}$ 程度の上昇となり，付図一 2 での 最高・最低値の差 $1.9 \mathrm{~g} / \mathrm{kg}$ 'の約 $1 / 2$ にしか過ぎない。した がって湿度センサの誤差だけに依存する結果でないことが推 察される。

以上から本現象が現実に起こっている可能性があるが，そ の理由をここで説明することはできないし，また本来の目的 でもない。必要なことは小屋裹等の熱湿気性状に対して，外 気の絶対湿度変動の影響がどの程度かの定量的な検討であり, それらについては别稿の数值解析において詳細に行なう。

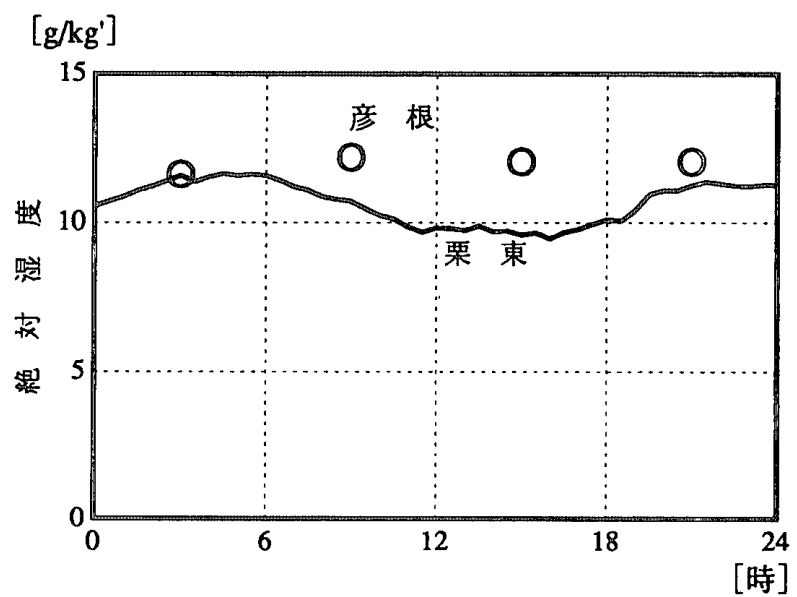

付図-1 栗東と彦根の絶対湿度の日変動

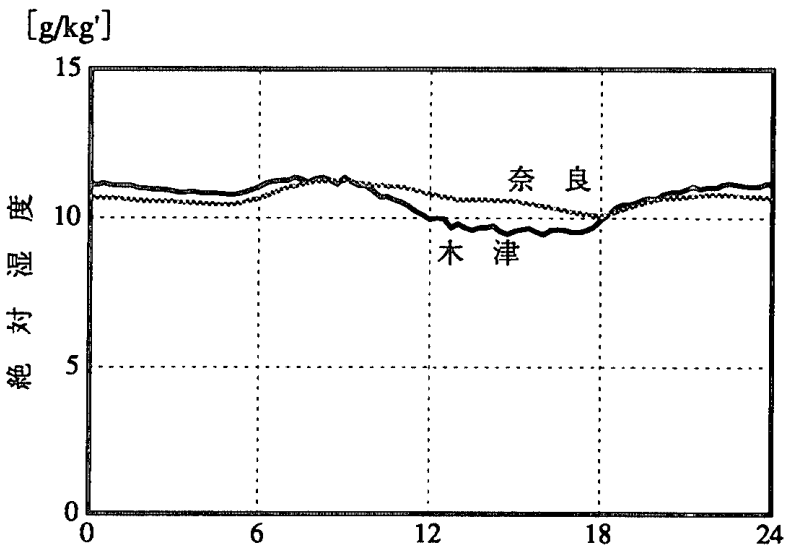

付図 -2 木津と奈良の絶対湿度の日変動

（1993 年 7 月 1 日原稿受理，1994 年 1 月 21 日採用決定） 